\title{
EFFECT OF NANOSTRUCTURED METAL SURFACE ON SEIRA SPECTRA OF ALBUMIN AND NUCLEIC ACIDS
}

\author{
G. Dovbeshko ${ }^{1}$, O. Fesenko ${ }^{1}$, A. Nazarova ${ }^{2}$ \\ 1 Institute of Physics of National Academy of Sciences of Ukraine, \\ 46 Nauky Ave., Kyiv, 03028, Ukraine \\ ${ }^{2}$ National Taras Shevchenko University of Kyiv, Biological Department, \\ 2 Glushkov Ave., Kyiv, Ukraine \\ (Received November 11, 2005; in final form - March 27, 2006)
}

\begin{abstract}
Advantages and disadvantages of the usage of different nanostructured gold surfaces, namely, rough gold and colloidal gold in SEIRA (surface enhanced infrared absorption) experiments are discussed. We have studied SEIRA spectra of biological polymers - DNA and bovine serum albumin. A small enhancement of the IR signal has been registered for multilayers of biopolymers (up to 7 in DNA on rough gold and up to 3 for albumin on colloidal gold) in comparison with small molecules (e. g. up 13 for Gly on rough gold). Alongside of this, we have registered a monolayer of albumin on rough gold. In this case the enhancement was more than 100. The most counspicuons disadvantage registered by us was connected with the influence of the colloidal gold on the DNA conformation. Colloidal gold could change the conformation state of A-DNA inducing the B-A conformation with elements of Z-form. We have found that rough gold does not practically influence the conformation state of DNA in comparison with those on $\mathrm{CaF}_{2}$ substrate.
\end{abstract}

Key words: DNA, BSA (bovine serum albumin), SEIRA (Surface Enhanced Infrared Absorption), glycine.

PACS number(s): 78.20.-e, 33.20.Ea.

\section{INTRODUCTION}

During the last decade spectroscopy of enhanced infrared (IR) signals from molecules located or attached to metal surface or metal particles has been effectively used for biological, electrochemical, surface, sensor and other applications [1-7]. The enhancement of the optical process by a factor of $10^{2} \ldots 10^{11}$ near rough metal surface (Au, Ag, Fe, etc.) has been already known for twenty years for both optical transitions in adsorbed molecules and the processes, which do not depend on the presence of molecules on metal surface [4]. These processes are surface-enhanced Raman scattering (SERS), surface enhanced infrared absorption (SEIRA), metal-enhanced fluorescence, second harmonics generation, etc. The effect consists in the essential increase of the intensity of transition (e.g. the effective cross-section increases by a factor of $10 \ldots 10^{4}$ for IR absorption) or efficiency of the process near metal surface. For the first time an enhancement of the infrared signal from molecules chemisorbed on $\mathrm{Au}$ and $\mathrm{Ag}$ surface by a factor up to $10^{3}$ has been registered by Harstein and colleagues in 1980 [2]. In 1991 the effect was named SEIRA by Osawa and Ikeda [6] by analogy with SERS. The explanation of the effect is not simple and includes several mechanisms, namely: (i) increase of the electromagnetic field near a rough metal surface or island metal films, or the so-called electrodynamic mechanism; (ii) increase of dipole transition moment of adsorbed molecules, or chemical mechanism [1,3-5]. A great contribution into the theoretical explanation of surface enhanced effects was made by Kosobukin $[4,8]$.

However, along with doubtless SEIRA advantages (high sensitivity of the method, detection of monolay- er film or lesser amount of substance up to $10 \mathrm{pg}[1,9]$, a possibility of determining orientation of the molecular groups, enhancement of intensity of some bands by 10-10 $0^{3}$ times, much improved observation of the bands due to surface selection rules) the method has some disadvantages. One of them is metal surface influence on SEIRA spectra in comparison with conventional FTIR spectra. Indeed, a high enhancement is achieved when absorbed molecules are situated more closely to the metal surface $[1,6]$. Usually these distances are about tens of angstroms or less. Naturally, small molecules could come closely to the metal surface in comparison with big molecules. In both cases nanostructured gold surface influences the molecule orientation and conformation. Here we present a study of gold surface influence upon vibration modes of DNA and albumin deposited on rough gold and colloidal gold surfaces.

\section{EXPERIMENTAL}

\section{A. Materials and methods}

In SEIRA experiments gold layers were obtained by vacuum deposition of 99.999 pure $\mathrm{Au}$ from molybdenum heater at the rate of $10-15 \AA / \mathrm{s}$ at room temperature substrate upon glass supports (TF-1 glass, $20 \times 20 \mathrm{~mm}$ ) via an intermediate adhesive $\mathrm{Cr}$ layer [10]. Before $\mathrm{Au}$ deposition, glass surface was cleaned by $\mathrm{NH}_{4} \mathrm{OH}: \mathrm{H}_{2} \mathrm{O}_{2}: \mathrm{H}_{2} \mathrm{O}$ and $\mathrm{HCl}: \mathrm{H}_{2} \mathrm{O}_{2}: \mathrm{H}_{2} \mathrm{O}$ solution subsequently, both 1:2:2 by volume concentration during 5 minutes at boiling temperature. Gold surface was rinsed in bidistilled water and dried in a flow of pure nitrogen after gold preparation and before biological molecule deposition. The thickness 
of gold layer was within 150-250 $\AA$ in different experiments. The $\mathrm{Cr}$ interlayer does not exceed 10-50 A. Size of roughness for gold film was about $50 \AA$ [7,11]. Sodium salt of calf-thymus DNA were obtained from Serva, bovine serum albumin (BSA) was obtained from Fluka and Sigma.

The samples for FTIR and SEIRA experiments were prepared by deposition of substances from $1 \mathrm{mg} / \mathrm{ml}$ DNA aqueous solution, $1 \ldots 5 \mathrm{mg} / \mathrm{ml}$ albumin in PBS solution on gold or $\mathrm{CaF}_{2}$ substrates. For preparation of BSA monolayer we applied the conventional method used for preparing samples in the SPR technique [10], namely we adsorbed BSA from BSA solution on gold $/ \mathrm{SiO}_{2}$ plate, rinsed it with distilled water until we reached the monolayer. Due to the fact that BSA contains free sulfhydryl groups which could form intermolecular bonds with gold, strong interaction between gold and BSA keep the monolayer of BSA on the surface of gold. We had no possibility to create a monolayer of DNA on gold surface without chemical modification of gold surface or/and without attaching to DNA additional molecules or molecular groups. In this case we will enhance this additional molecular layer more strongly than DNA and spectra will be overlapped. So, this method is proper for other than SEIRA studies. In SEIRA it is better to use such a metal surface that has a possibility to form a strong interaction between metal surface and molecules under study as in the case of BSA on gold.

Colloidal gold nanoparticles of the size of $15-400 \AA$ were produced by reduction of $\mathrm{Au}$ from $\mathrm{HAuCl}_{4}$ with sodium citrate and the concentration of $12 \mathrm{mg} / \mathrm{ml}$. Then they were mixed with sodium salt of calf-thymus DNA (highly polymerised) aqueous $5 \cdot 10^{-3} \mathrm{M}$ solution, kept in refrigerator for 24 hours, precipitated on gold substrate as well as on $\mathrm{CaF}_{2}$ and dried lyophilically. We prepared the samples mixing $10 \mu \mathrm{l}$ of colloidal gold per $10 \mu \mathrm{l}$ of DNA solution. As a reference the same DNA aqueous solution without colloidal gold was used. BSA aqueous solution of $1 \ldots 5 \mathrm{mg} / \mathrm{ml}$ concentration was mixed with colloidal gold, stirred and then precipitated on $\mathrm{CaF}_{2}$.

\section{B. FTIR and SEIRA spectroscopy}

IR spectra were collected in the $500-5300 \mathrm{~cm}^{-1}$ region with IFS-66 Bruker instrument in conventional transmittance mode for DNA and BSA on $\mathrm{CaF}_{2}$ substrate and

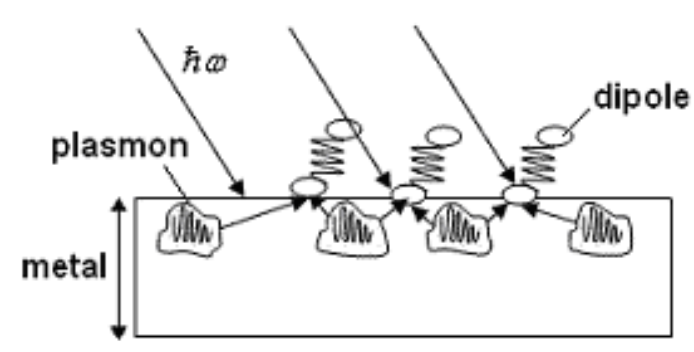

Fig. 1. Mechanism of enhancement on metal surface (SEIRA). in reflectance-absorbance (RA) mode on gold substrate. The reflectance attachment used in the experiment has the light incidence angle close to $16.5^{\circ}$ [7]. Spectra evaluation was performed with Opus 2.2 software. The position of the bands was estimated by the method of second derivative and/or standard method. Accuracy of frequency values in the spectra was equalled to $0.5 \mathrm{~cm}^{-1}$ and of absorption values to 0.0005 a.u. We used the normalised spectra to $\mathrm{OH}$ stretching vibration in the 3300 $3400 \mathrm{~cm}^{-1}$ range for comparison of shape of the bands for DNA and normalized to Amid 1 for albumin.

The experimental factors of enhancement $\left(g^{2}\right)$ were determined as a ratio of peak intensity of the bands for substances on gold surface in reflectance mode to those on $\mathrm{CaF}_{2}$ substrate in conventional geometry.

Principal component analysis was applied to SEIRA spectra of DNA. One principal component was chosen as the ratio of intensity of maximum of the phosphate asymmetrical band (in the $1240-1230 \mathrm{~cm}^{-1}$ region) to the intensity of maximum in the $3400-2300 \mathrm{~cm}^{-1}$ region, which is assigned to $\mathrm{OH}$ stretching vibration. According to M. Shie [12] this component multiplied by 5.25 characterizes the number of water molecules per nucleotide. The second principal component was the ratio of the intensities at $1712 \mathrm{~cm}^{-1}$ and $1700 \mathrm{~cm}^{-1}$ that is a characteristic of the conformation state of DNA relating to $\mathrm{A}, \mathrm{B}$ or Z-form. In principal component coordinate system every SEIRA spectra could be represented by one point. The location of these points depends on the value of the principal components. This data give a possibility to determine the conformational type of nucleic acids as it was applied by us for conformation analysis of DNA from viruses [13] and cancer cells [14] earlier.

\section{RESULTS AND DISCUSSION}

The energy scheme of the mechanism of the enhancement effect is presented in Fig. 1, 2. IR photon excites both adsorbed molecules and plasmons in metal (Fig. 1) at the wing of plasmon resonance band (insertion on Fig. 2).

Then the energy from plasmon vibrations is transferred to the adsorbed molecules to increase molecular absorbance.

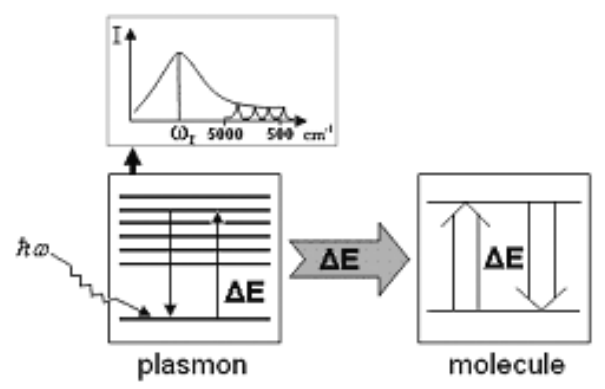

Fig. 2. Energy scheme of enhancement mechanism. 


\section{A. SEIRA spectroscopy of DNA on gold}

The DNA double strand could adopt different conformation states which has different symmetry, pinch of strand, number of nucleotides per helix, etc. and depends on the environment, humidity, $\mathrm{pH}$, ionic force, etc. [15]. These are well-known A, B (right) and Z (left) form of DNA (Fig. 3). In vibration spectra these forms have dis- tinctive features: the "so-called" marker bands and that is why FTIR spectra could be used for characterizing these conformations [16-17]. However, gold could influence the conformation state of DNA, as well as change their marker band positions. We have modeled the A and B form of DNA on rough gold by changing humidity from $100 \%$ (B-form) to $65 \%$ (A-form), however, we did not model the Z-form of DNA on rough gold (see Table 1).

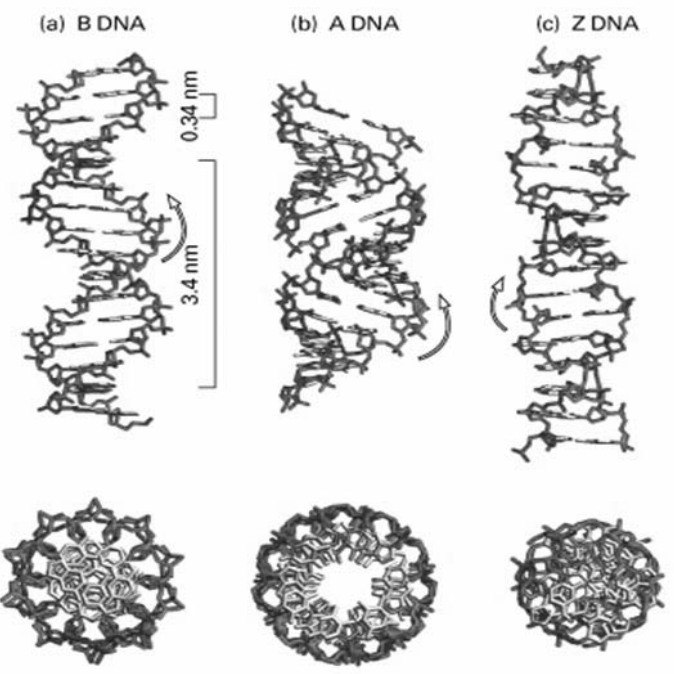

Fig. 3. DNA forms: (a) - B form, (b) - A form, Z form.

Earlier we have repeatedly studied the DNA $[14,18,19]$ on rough gold substrate and concluded that gold substrate did not practically influence the vibration modes and macromolecular conformations of DNA [7,18]. We have found only some minor distinctive features of DNA on gold substrate. The factor of enhancement was registered to 3-7 for different molecular groups; the mass of substance was equal to $1 \ldots 10 \mu \mathrm{g}$. In this case the shift of many vibrations was around $2-3 \mathrm{~cm}^{-1}$ for DNA on gold in comparison with DNA on $\mathrm{CaF}_{2}$, shift of complex stretching of the $\mathrm{OH}-\mathrm{NH}-\mathrm{CH}$ band was $5-10 \mathrm{~cm}^{-1}$ (Fig. 4), conformation of the molecules of DNA on $\mathrm{CaF}_{2}$ was the same as those for DNA on rough gold and close to A-form. The latter could be explained by the fact that the majority of the spectral markers for $\mathrm{Na}-\mathrm{DNA}$ on the gold substrate are close to the markers of A-form [13] for DNA of $75 \%$ humidity.
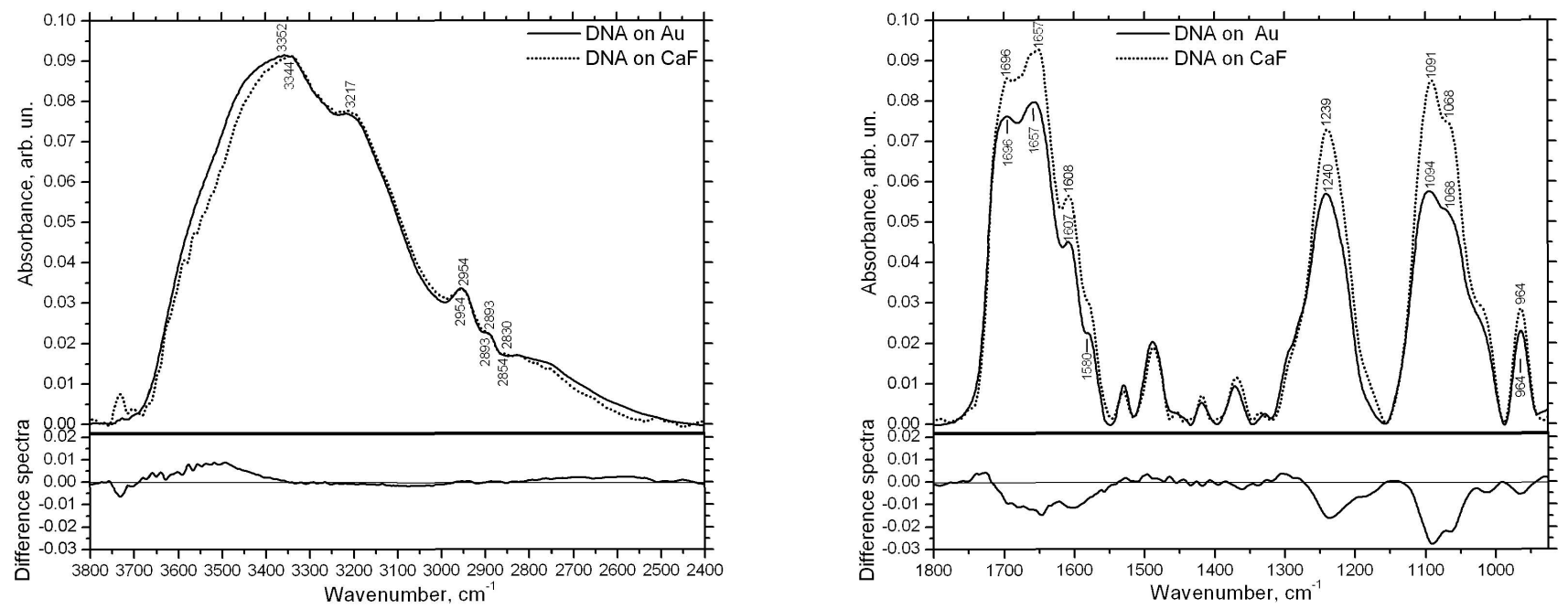

Fig. 4. SEIRA spectra of DNA (normalised to $\mathrm{OH}$ stretching vibration) on gold substrate in comparison with $\mathrm{DNA}$ on $\mathrm{CaF}_{2}$ substrate in the $3800-2400 \mathrm{~cm}^{-1}$ range (left) and $1800-800 \mathrm{~cm}^{-1}$ range (right). 
The same is valid for B-form of DNA of $95 \%$ humidity [14] and principal component analysis gives a possibility to visualise it [18] (Fig. 5).

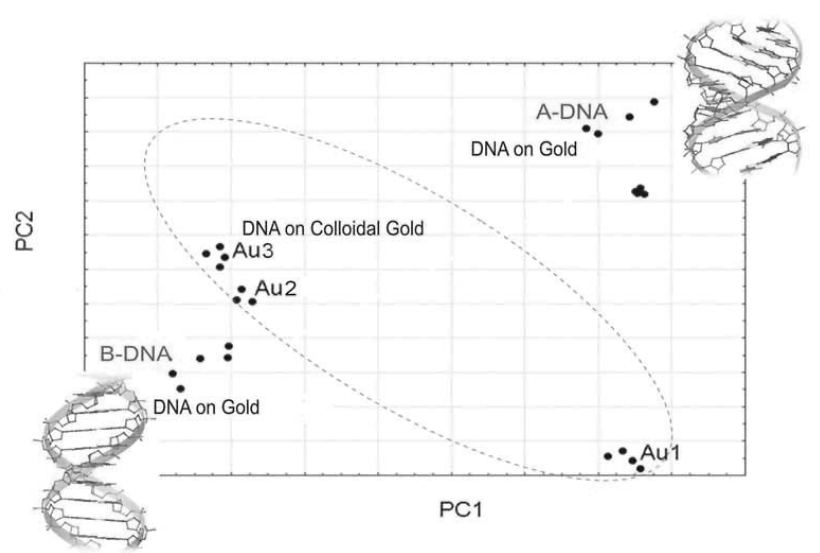

Fig. 5. Principal component analysis of free film of DNA in A and B forms; $\mathrm{A}$ and B DNA on gold and DNA with colloidal gold of $10 \mu \mathrm{l}, 20 \mathrm{ml}$ and $30 \mathrm{ml}$ per $10 \mathrm{ml}$ DNA of $5 \cdot 10^{-3} \mathrm{M}$, assigned to Au1, Au2, Au3, accordingly.
Analysing the sugar region of DNA spectra, namely the region lower than $1000 \mathrm{~cm}^{-1}$ (Table 1), we must assume that any substrate can strongly influence the sugar conformation of DNA, even in the case when other structural components are not perturbed. In our case, we observed that the gold substrate induces the conformational changes of the sugars' residuals if they come close to gold surface. It is well known that sugars in A-DNA have characteristic features at $805 \mathrm{~cm}^{-1}$ and $860 \mathrm{~cm}^{-1}$ as well as for B-DNA - at $832 \mathrm{~cm}^{-1}$. The band observed at 834 and $832 \mathrm{~cm}^{-1}$ for A and B-form DNA [19], respectively, appears presumably due to reformation of intermolecular H-bonding ( $\mathrm{NH}, \mathrm{OH}$ and $\mathrm{CH}$ groups) near the gold substrate [20] as a result of DNA bending at gold peaks. As usual, we observed a band near $830 \mathrm{~cm}^{-1}$ for free film of A-DNA prepared on $\mathrm{CaF}_{2}$ substrate and then taken from substrate. Therefore, this feature is not due to gold substrate but for reformation of bonds near the interface. A similar process was reported earlier by Gaigeot et al. [22] in connection with non-coincidence of the data obtained with inelastic scattering of nucleic acid blocks, in solid state and calculations with density functional theory for the spectral region under $900 \mathrm{~cm}^{-1}$. It has been shown that intermolecular $\mathrm{H}$-bonds were formed in the film involving $\mathrm{N}_{1}-\mathrm{H}$ and $\mathrm{N}_{3}-\mathrm{H}$ groups of the bases giving a strong band at the $830 \mathrm{~cm}^{-1}$.

\begin{tabular}{|c|c|c|c|c|c|}
\hline A-form & B-form & Z-form & A-form on gold & B-form on gold & Assignment \\
\hline $1700-1709$ & $1714-1718$ & $1692-1700$ & 1700 & 1715 & C=O bases \\
\hline $1234-1240$ & $1220-1225$ & 1215 & $1230-1240$ & $1222-122$ & $\mathrm{PO}_{2}$-asym. \\
\hline $1089-1090$ & 1085 & $1060-1065$ & $1084-1091$ & 1088 & $\mathrm{PO}_{2}$-sym. \\
\hline $860-864$ & - & $864-867$ & $859-860$ & - & sugar $C 3^{\prime}$-endo \\
\hline- & $841-835$ & $834-838$ & $832-834$ & 834 & sugar $C 2^{\prime}$-endo \\
\hline $805-808$ & - & - & $803-805$ & - & sugar $C 3^{\prime}$-ендо \\
\hline
\end{tabular}

Table 1. Marker models of DNA in A and B forms taken from Schrader [16] and Taillandier [17,21] and DNA on rough gold substrate

\section{B. Effect of colloidal gold on DNA}

An essential change in vibration mode position, halfwidth and intensity in SEIRA spectra of DNAcolloidal gold in comparison with FTIR spectra of DNA on $\mathrm{CaF}_{2}$ have been observed (Fig. 6).

The greatest changes for DNA-colloidal gold system were observed for the $\mathrm{OH}-\mathrm{NH}-\mathrm{CH}$ band, namely, an increase of the halfwidth of $\mathrm{OH}$ and $\mathrm{NH}$ stretching bands ca. $250 \mathrm{~cm}^{-1}$ and their high frequency shift of about $100 \mathrm{~cm}^{-1}$. A decrease in the intensity of the phos- phate bands at $1104 \mathrm{~cm}^{-1}$ (symmetric stretching) 2.4fold and at $1240 \mathrm{~cm}^{-1}$ (asymmetric stretching) 2-fold; a decrease in the intensity of the base bands at 1800$1550 \mathrm{~cm}^{-1}$ (1.3-folds), an increase of halfwidth of phosphate bands about $35-40 \mathrm{~cm}^{-1}$ for asymmetric phosphate; a high frequency shift of asymmetric phosphate from 1240 to $1244 \mathrm{~cm}^{-1}$, appearance of shoulder at 1222$1215 \mathrm{~cm}^{-1}$ (characteristics of $\mathrm{Z}$ form); a high frequency shift of symmetric phosphate from 1093 to $1104 \mathrm{~cm}^{-1}$; a decrease of shoulder band of symmetric phosphate at 1050-1070 $\mathrm{cm}^{-1}$ (characteristics of $\mathrm{Z}$ form) have been registered as well. The DNA with colloidal gold does 
have features of both A, B and Z-form. Indeed, canonical forms of DNA are present here too, especially B and Z-forms $\left(930 \mathrm{~cm}^{-1}\right)$ and there is a reduction of A-form $\left(860 \mathrm{~cm}^{-1}\right)$ [23]. The intensity of the band at $960 \mathrm{~cm}^{-1}$ and at the frequencies that are decreased about 1.5 to 2-fold (characteristics of $\mathrm{Z}$ form). Principal component analysis was applied for the conversion of the different spectra in separate points. Such a presentation (Fig. 5) shows that the points corresponding to canonical DNA (A and $\mathrm{B}$ form) and DNA-colloidal gold have different region of localization in the principal component plane. In this plane the DNA-colloidal gold is close to A-B-form with same elements of Z-form, however, our experimental condition induces A-form.
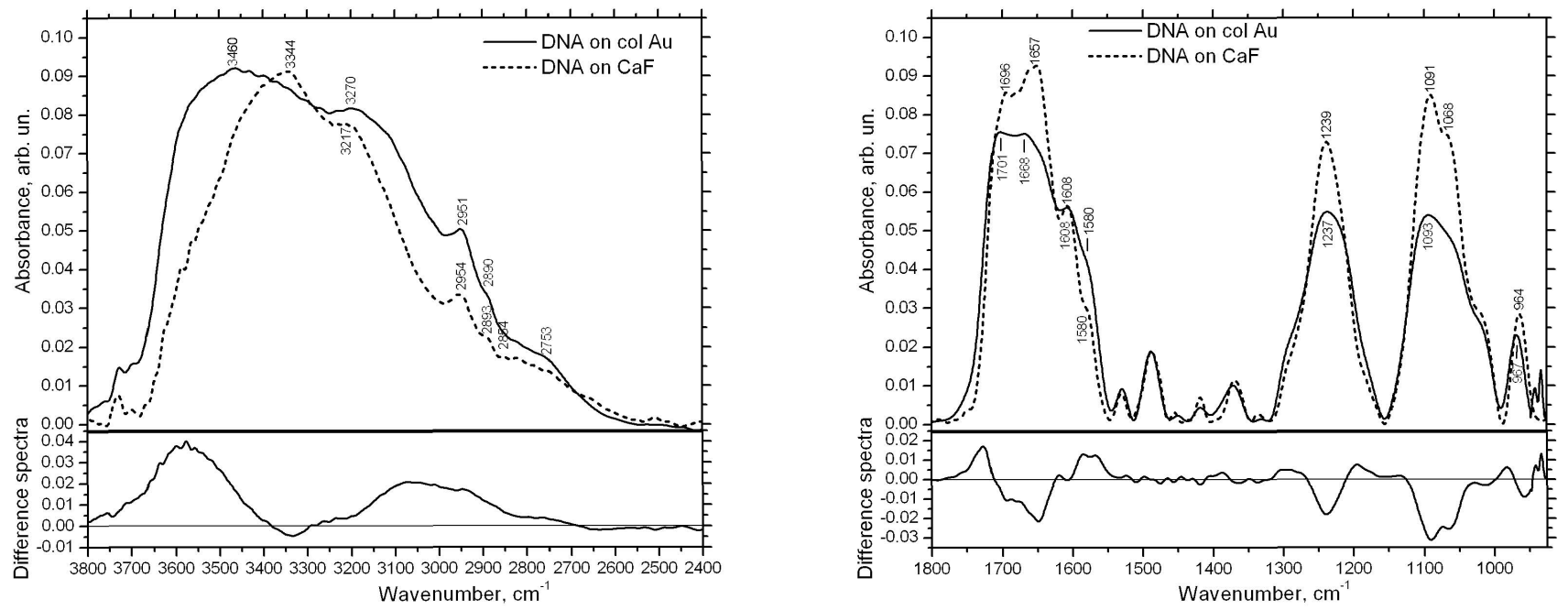

Fig. 6. SEIRA spectra of DNA (normalised to $\mathrm{OH}$ stretching vibration) on colloidal gold in comparison with DNA on $\mathrm{CaF}_{2}$ substrate in the $3800-2400 \mathrm{~cm}^{-1}$ (left) and $1800-800 \mathrm{~cm}^{-1}$ (right).

\section{BSA on gold and colloidal gold}

\section{Multilayer BSA coverage on gold.}

Characteristic features of any proteins in vibrational spectra are Amid (A, B, I, II, III, IV, V, VI, VII) bands with the vibration NHCO unit (Fig.7). The amid I vibration, absorbing near $1650 \mathrm{~cm}^{-1}$, arises mainly from the $\mathrm{C}=\mathrm{O}$ stretching vibration with minor cotributions from the out-of-phase CN stretching vibration, CCN deformation and the $\mathrm{NH}$ in-plane bend. The latter is responsible for the sensitivity of the amide I band to N-deuteration of the backbone. The amid I vibration is hardly affected by the nature of the side-chain. It depends, however, on the secondary structure of the backbone and is therefore the amide vibration that is most commonly used for secondary-structure analysis.

The amid II mode is the out-of-phase combination of the $\mathrm{NH}$ in-plane bend and the $\mathrm{CN}$ stretching vibration with smaller contributions from the $\mathrm{CO}$ in-plane bend and the $\mathrm{CC}$ and $\mathrm{NC}$ stretching vibration with smaller contributions from the $\mathrm{CO}$ in-plane bend and the $\mathrm{CC}$ and $\mathrm{NC}$ stretching vibrations. As for the amide I vibration, the amide II vibration is hardly affected by sidechain vibrations but the correlation between secondary structure and frequency is less straightforward than for the amide I vibration.
The amide III is the in-phase combination of the $\mathrm{NH}$ bending and $\mathrm{CN}$ stretching vibrations with small contributions from the $\mathrm{CO}$ in-plane bending and the $\mathrm{CC}$ stretching vibration. In polypeptides, the composition of this mode is more complex, since it depends on side-chain structure and since $\mathrm{NH}$ bending contributes to several modes in the 1400 to $1200 \mathrm{~cm}^{-1}$ region. Contributions of backbone and side-chain vibrations vary considerably which makes the amide III vibration less suited for secondary structure analysis.

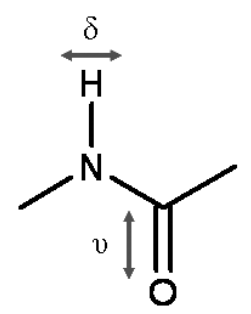

Fig. 7. Structure of NHCO group of any protein.

We have studied the enhancement of BSA on gold and on colloidal gold surface and found that the main marker band of protein-Amid 1 does not show a big enhancement -2.2 for colloidal gold (Fig. 8) and 1.3 for rough 
gold (Table 2). This is in a good agreement with the data obtained by Kuhle et al [24]. They registered an enhancement factor for Amid 1 equaled to 1.4. Unfortunately, this band is important for conformation analysis of proteins. However, some other bands could show more enhancements - up to 5. Another disadvantage of the SEIRA study of BSA on gold is connected with the absorbance dependence on solution concentration [25]. We have not observed absorbance dependence for DNA in the $10^{-2}-10^{-4} \mathrm{M}$ region concentration and for BSA solution of up to $1-5 \mathrm{mg} / \mathrm{ml}$ where Bugger-Beer low is valid for Amid A, Amid 1, Amid 2. Our study showed that colloidal gold is a better enhancer than rough gold for BSA multilayer films. In some cases the SEIRA spectra of the BSA-colloidal gold system have registered an evident shift of Amid I band from 1651 to $1588 \mathrm{~cm}^{-1}$ caused by the overlap of spectra of protein and colloidal gold [25]. It should be taken into account in studies of BSA with colloidal gold.

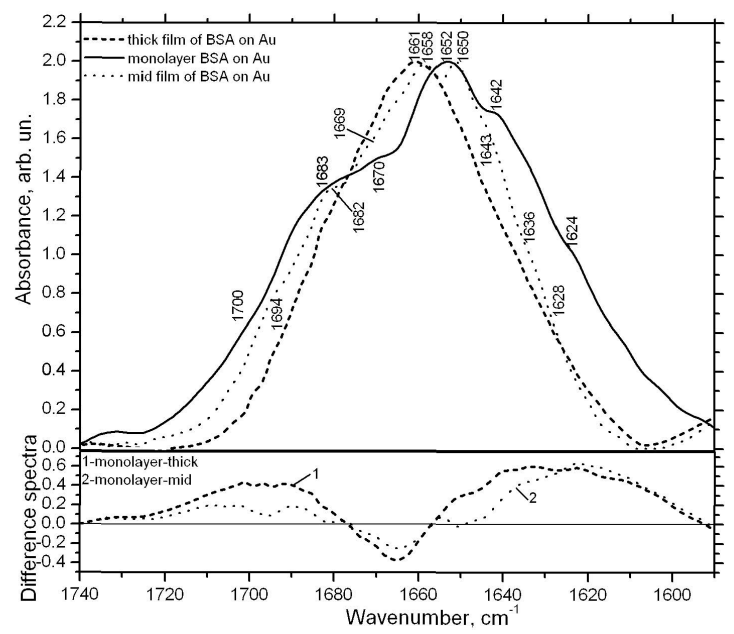

Fig. 8. SEIRA spectra of BSA monolayer, thin and thick layer in the region Amid I band (1750-1600 $\left.\mathrm{cm}^{-1}\right)$.

\begin{tabular}{|c|c|c|c|c|c|c|c|c|c|c|c|}
\hline \multicolumn{3}{|c|}{ DNA on $\mathrm{Au}$ [18] } & \multicolumn{3}{|c|}{ Guanine on $\mathrm{Au}$ [11] } & \multicolumn{3}{|c|}{$\begin{array}{c}\text { BSA on Au and } \\
\text { (colloidal gold) (Fig. 9) }\end{array}$} & \multicolumn{3}{|c|}{ Gly on $\mathrm{Au}[26]$} \\
\hline $\begin{array}{c}\text { Band } \\
\text { position } \\
\mathrm{cm}^{-1}\end{array}$ & $g^{2}$ & $\begin{array}{c}\text { Band } \\
\text { assign- } \\
\text { ment }\end{array}$ & $\begin{array}{c}\text { Band } \\
\text { position } \\
\mathrm{cm}^{-1}\end{array}$ & $g^{2}$ & $\begin{array}{c}\text { Band } \\
\text { assign- } \\
\text { ment }\end{array}$ & $\begin{array}{c}\text { Band } \\
\text { position } \\
\mathrm{cm}^{-1}\end{array}$ & $g^{2}$ & $\begin{array}{c}\text { Band } \\
\text { assign- } \\
\text { ment }\end{array}$ & $\begin{array}{c}\text { Band } \\
\text { position } \\
\mathrm{cm}^{-1}\end{array}$ & $g^{2}$ & $\begin{array}{c}\text { Band } \\
\text { assign- } \\
\text { ment }\end{array}$ \\
\hline 1653 & 2.9 & $\begin{array}{l}\mathrm{C}=\mathrm{O}, \\
\mathrm{C}=\mathrm{N}, \\
\mathrm{N}=\mathrm{H}\end{array}$ & 1633 & 5.0 & $\begin{array}{l}\text { def } \mathrm{NH}, \\
\operatorname{strCN}\end{array}$ & $\begin{array}{l}1660 \\
(1654)\end{array}$ & $\begin{array}{l}1,3 \\
2,2\end{array}$ & Amid I & 1585 & 7.9 & $\begin{array}{l}\mathrm{COO}^{-} \\
\text {as str }\end{array}$ \\
\hline 1230 & 2.4 & $\mathrm{PO}_{2}^{-}$ & 1417 & 6.2 & $\begin{array}{c}\text { def CNH, } \\
\text { str CN }\end{array}$ & $\begin{array}{c}1547 \\
(1545)\end{array}$ & $\begin{array}{l}1.5 \\
2,1\end{array}$ & Amid II & 1499 & 12.6 & $\begin{array}{c}\mathrm{NH}_{3}^{+} \\
\text {sym def }\end{array}$ \\
\hline 1084 & 2.1 & $\mathrm{PO}_{2}^{-}$ & 1372 & 6.0 & $\begin{array}{c}\text { str CN, } \\
\text { str CC, } \\
\text { def } \mathrm{CNH}\end{array}$ & 1302 & 2.0 & Amid III & 1333 & 11.7 & $\begin{array}{c}\mathrm{CH}_{2} \\
\text { def, } \\
\mathrm{NH} \text { bend }\end{array}$ \\
\hline 963 & 2.4 & $\begin{array}{l}\mathrm{C}-\mathrm{C} \\
\mathrm{C}-\mathrm{O}\end{array}$ & 1313 & 7.3 & def $\mathrm{NCH}$ & 1245 & 1.9 & Amid III & 1409 & 5.7 & $\begin{array}{l}\mathrm{COO}^{-} \\
\text {sym str }\end{array}$ \\
\hline 831 & 2.0 & $\begin{array}{c}\mathrm{C}_{2} \\
\text { endo }\end{array}$ & 1119 & 3.1 & $\begin{array}{l}\text { def CNH, } \\
\text { str CN }\end{array}$ & - & - & - & 1134 & 3.2 & $\begin{array}{c}\mathrm{CH}_{2} \\
\text { bend, } \\
\mathrm{NH}_{3}^{+} \text {rock }\end{array}$ \\
\hline
\end{tabular}

Table 2. Experimental factor of enhancement for DNA, BSA on gold in comparison with guanine and glycine.

\section{Monolayer of BSA on gold.}

SEIRA has allowed us to register a monolayer of BSA on rough gold (Fig. 9) that confirms a possibility to reach a big enhancement (more than 100) in the case of monolayer or less. It is impossible to obtain and register a monolayer film on $\mathrm{CaF}_{2}$ substrate in any FTIR mode.

The spectra of monolayer were compared with the spectra of mid and thick BSA film on gold substrate.
Some specific differences in the spectra of monolayer and thicker films were observed.

The first by the halfwidth of Amid 1 monolayer is wider about $15-22 \mathrm{~cm}^{-1}$ in comparison with other layers and second, by the shape of the band was changed in comparison with those for a thick film. Namely, the following positions of absorption bands were registred in the spectra of monolayer (in brackets the frequency for mid film is shown): $\alpha$-helix - 1652 (1650); $\beta$-sheet -1624 (1628), no band (1636, this band position corresponds 
also to the deformation vibration of water), 1642 (1643), 1670 (1669); unordered coil - no band (1658), turns 1700 (1694), 1683 (1682) $\mathrm{cm}^{-1}$. This means a strong interaction between protein and gold as well as the rearrangement of contributions of the absorption bands attributed to the various types of protein conformation, i. e. $\alpha$-helix, $\beta$-sheet, unordered coil, turns. This situation has complicated the fitting procedure and conformation analysis of BSA.

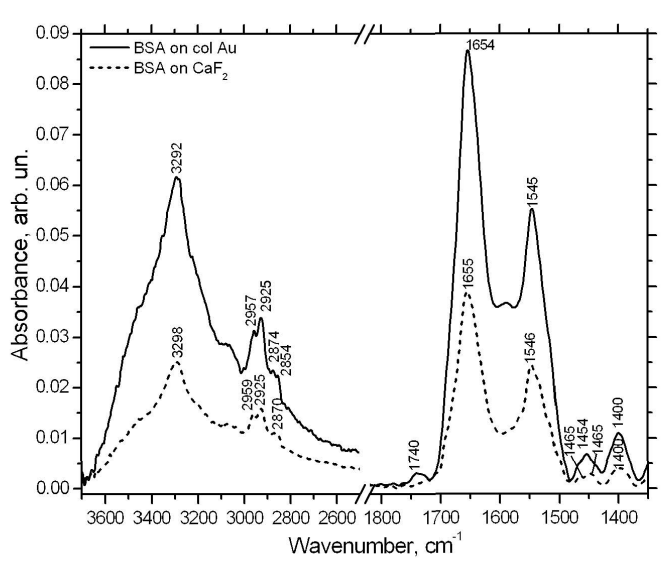

Fig. 9. SEIRA spectra of BSA on colloidal gold in comparison with $\mathrm{BSA}$ on $\mathrm{CaF}_{2}$.

\section{CONCLUSIONS}

1. It is really small (less than 10) an enhancement for complex molecules as BSA and DNA in the case of a multilayer coverage and more then 100 for the monolayer of BSA (for DNA we could not reach it due to the fact that DNA covalently bound with gold only with additional molecules). For small molecules, even for multilayer coverage, enhancement reach to $10-20$ and as a rule is more than those for complex molecules.

2. Colloidal gold could change the conformation of DNA in contrast with rough gold in the case of DNA multilayer coverage. However, for the enhancement of multilayer coverage of BSA, the colloidal gold is a better enhancer.

3. A high enhancement has a correlation with more numerous spectra distortion.

\section{ACKNOWLEDGMENTS}

We are greatly indebted to the Foundation of Fundamental Research of the Ministry of Sciences and Educations of Ukraine and a special sensor programme (N39 ВЦ C 145/44) of the Academy of Sciences of Ukraine for financial assistance.
[1] M. Osawa, Handbook of Vibrational Spectroscopy (Wiley, Chichester) 1, 785 (2002).

[2] A. Hartstein, J. R. Kirtley, J. C. Tsang, Phys. Rev. Lett. 45, 201 (1980).

[3] R. Chang, T. Furtak, Surface Enhanced Raman Scattering (Plenum Press, New York-London, 1982).

[4] V. Kosobukin, Poverkhnost' 12, 5 (1983).

[5] V. Emelyanov, N. Koroteev, Usp. Fiz. Nauk 135, 345 (1981).

[6] M. Osawa, M. Ikeda, J. Phys. Chem. 95, 9914 (1991).

[7] G. Dovbeshko, V. Chegel, N. Gridina, et al., Proc. SPIE 4425, 158 (2001).

[8] V. Kosobukin, Izv. vuzov, fizika 49, 1111 (1985).

[9] Z. Zhang, T. Imae, J. Colloid Interface Sci. 233, 99 (2001).

[10] G. Beketov, Yu. Shirshov, V. Chegel, Sensors and Actuators 3, 432 (1998).

[11] G. Dovbeshko, O. Fesenko, V. Chegel, Yu. Shirshov, Semicond. Phys. Quant. Electronics Optoelectronics 7, 215 (2004).

[12] M. Shie, Ph. D. thesis, Institute of Biophysics, Pushchino, Moscow (1977).

[13] G. Dovbeshko, O. Repnytska, T. Pererva, et al., Proc. SPIE 5507, 309 (2004).

[14] O. Repnytska, G. Dovbeshko, V. Tryndiak, I. Todor, D. Kosenkov, Faraday Discuss. 126, 61 (2004).

[15] W. Senger, Principles of Nucleic acid Structure
(Springer, New York-Toryo, 1987)

[16] B. Schrader, Infrared and Raman Spectroscopy (VCH Publishers Inc., New York, 1995).

[17] E. Taillandier, J. Liquier, J. Taboury, Adv. Infrared Raman Spectroscopy, 65 (1985).

[18] G. Dovbeshko, V. Chegel, N. Gridina, O. Repnytska, Yu. Shirshov, V. Tryndiak, I. Todor, G. Solyanik, Biospectroscopy 67, 470 (2002).

[19] G. Dovbeshko, O. Repnytska, V. Chegel, Yu. Shirshov, G. Solyanik, V. Tryndyak, I. Todor, A. Zinyo, Biophys. Bull. Kharkiv Univ. 528, 93 (2001).

[20] A. Boal, V. Rotello, Langmuir 16, 9527 (2000).

[21] M. Ghomi, R. Letellier, J. Liquier, E. Taillandier, Int. J. Biochem. 22, (1990).

[22] M. Gaigeot, N. Leulliot, M. Ghomi, H. Jobic et al., Chem. Phys. 261, 217 (2000).

[23] G. Dovbeshko, O. Gnatyuk, V. Chegel, et al., Semicond. Phys. Quant. Electronics Optoelectronics 7, 318 (2004).

[24] Ch. Kuhne, G. Steiner, W. Fischer, R. Salzer, Fresenius J. Anal. Chem. 360, 750 (1998).

[25] G. Dovbeshko, O. Paschuk, O. Fesenko, V. Chegel, Yu. Shirshov, A. Nazarova, D. Kosenkov, Frontiers of Multifunctional Integrated Nanosystems (Kluwer Academic Publishers, Netherlands) 61, 447 (2004).

[26] G. Dovbeshko, O. Fesenko, V. Chegel, Yu. Shirshov, D. Kosenkov, A. Nazarova, Asian Chem. Lett. 10, 50 (2006). 


\title{
ВПЛИВ НАНОСТРУКТУРОВАНИХ ЗОЛОТИХ ПОВЕРХОНЬ НА SЕIRА СПЕКТРИ АЛЬБУМІНУ ТА НУКЛЕЇНОВИХ КИСЛОТ
}

\author{
Г. Довбешко ${ }^{1}$, О. Фесенко ${ }^{1}$, А. Назарова ${ }^{2}$ \\ ${ }^{1}$ Інститут фізики Національної академї̈ наук Украӥни, просп. Науки, 46, Київ, 0зо28, Украӥна \\ ${ }^{2}$ Начіональний університет ім. Тараса Григоровича Шевченка, просп. Глушкова, 2, Київ, Украӥна
}

У статті обговорено переваги та недоліки використання різних наноструктурованих золотих поверхонь, а саме, шорсткого й колоїдного золота в SEIRA (Surface Enhanced Infrared Absorption) експериментах 3 підсилення інфрачервоного поглинання біологічних полімерів - ДНК та альбуміну металевою поверхнею. Незначне підсилення ІЧ сигналу зареєстровано для багатошарової плівки біополімерів на золотій поверхні, а саме, для ДНК на шорсткому золоті - близько 7, для альбуміну на колоїдному золоті - 3. Для мономерів, або простих молекул, коефіцієнт підсилення був більшим, зокрема для гліцину на шорсткому золоті становив близько 13. Значне підсилення 100 вдалося зареєструвати для моношару альбуміну на шорсткому золоті. Найбільший недолік використання ефекту SEIRA пов'язаний із впливом колоїдного золота на конформацію молекул ДНК. Колоїдне золото може нав'язувати конформацію, у якій наявні маркерні смуги А-B та Zформи, на відміну від шорсткого золота, що практично не впливає на конформаційний стан ДНК. 